\title{
THE COUNTRY-OF-ORIGIN EFFECT IN THE SELECTED TRANSPORT SERVICES
}

\begin{abstract}
Summary
The country-of-origin effect has a multi-dimensional character. Neglecting the impact of COO's dimensions in the evaluation of the selected services may result in some simplified, inaccurate conclusions. The aim of the presented research was: 1) to determine an in-depth COO rate in the evaluation of transport services; 2) to determine a relation between the $\mathrm{COO}$ effect of a particular country in the evaluation of transport services and the readiness to purchase the particular service in this country. The research results indicate a strong relation between the $\mathrm{COO}$ effect and the readiness to purchase the particular service in this country: the higher the $\mathrm{COO}$ effect is, the higher readiness to purchase the service becomes.
\end{abstract}

Keywords: country-of-origin effect, transport services, survey results

\section{Introduction}

In an article published in 1965, R.D. Schooler, as the first author ever, raised the question of perception of imported goods and the impact of such perception on buyers' opinions. This phenomenon was referred to as the country-of-origin effect, and in the subsequent years it became one of the most often analysed problem in expert literature concerning international marketing and consumers' behaviour in

\footnotetext{
${ }^{1}$ monika.boguszewicz@gmail.com.

2 emagier@wsb.gda.pl.

3 sokkat@wp.pl.
} 
the reference to material products. The effect of the country-of-origin is much less known and analysed when we consider services. ${ }^{4}$

Considering liberalisation tendencies in the legal regulations, which refer to the international trade of services and technological advance, the significance of the cross-border service trade is expected to increase. In the result a necessity of intensifying the research on the $\mathrm{COO}$ in services appears to be well-grounded. Their specific characteristics indicate that transferring conclusions, which result from the analysis carried out for tangible products should not take place automatically.

Low-cost airlines as well as courier companies can be used as the examples of dynamically developing sectors on the Polish market. Their customers may take advantage of a number of offers provided by the companies from various countries.

The process of deregulating the market of airline connections in Poland started in 2004, with the access to the European Union. In consequence, this liberalisation resulted in the increase in the number of airlines operating in Poland (from 30 in 2003 to 46 in 2008). ${ }^{5}$ It caused the increase in competition on particular connection lines. The low-cost carriers turned out to be important players in this market. In 2014 they transported $54.30 \%$ of passengers. The first position on the Polish market of air passenger transport among them was taken by Ryanair, with its share at the level of $27.95 \%$. The third position (just behind PLL LOT) was taken by WizzAir (19.27\% of the market share). No other low-cost carriers (Norwegian Air Shuttle, EasyJet, Air Berlin, Germanwings, Vueling Airlines, AirBaltic, Jet2.com, WowAir) exceeded the level of $2.60 \%$ of the market share in the market of air transport services in Poland. ${ }^{6}$

In Poland, the formation of a real market of courier services started in 1989, during the social and economic transformation time, when the domestic market opened to the world. Then a number of national enterprises were established, and

\footnotetext{
${ }^{4}$ Authorial literature review, see W. Czakon, Metodyka systematycznego przegladu literatury, in: Podstawy metodologii badań w naukach o zarzadzaniu, ed. W. Czakon, Oficyna Wolters Kluwer business, Warszawa 2013, p. 51 based on the ESBCO and ProQuest database of publications. The question of the $\mathrm{COO}$ in services is presented in a broader scope in: M. BoguszewiczKreft, Efekt kraju pochodzenia w ustugach, w: Sektor ustug - uwarunkowania i tendencje rozwoju, Prace Naukowe Uniwersytetu Ekonomicznego we Wrocławiu nr 353, Wyd. Uniwersytetu Ekonomicznego, Wrocław 2014, p. 79-89.

${ }^{5}$ UOKiK: Wpływ liberalizacji rynku połaczeń lotniczych na konkurencję na tym rynku, Departament Analiz, luty 2010, p. 4.

${ }^{6}$ Civil Aviation Authority, Statistics by carriers, www.ulc.gov.p1/p1/czesto-zadawane-pytaniafaq/348-ler/3725-statystyki-wg-przewoznikow (24.05.2015).
} 
the subsidiaries of the largest global companies operating in this sector appeared. At present, there are about 200 business entities which operate in the CEP sector (courier, express and parcel delivery services) and among them many international companies can be mentioned. ${ }^{7}$ Despite the fact that the market of courier services is developing very fast, using this type of services in Poland per one person turns out to be several times lower in comparison to the countries, which have been the members of the European Union much longer. Therefore, it may be reasonable to expect some growing tendencies in their development. ${ }^{8}$ Courier companies come as a good example of providing services, the development of which is strongly affected by the internet services. In fact, fast development of e-shops is actually the reason for dynamic development of the courier services sector. In 2013 internet shops sent almost 25\% of all the deliveries. Considering the fact that the number of e-shops in Poland differs significantly from the number of e-shops in Europe (in 2013 this number was evaluated to be about 14 thousands, comparing that to 100 thousands in Germany and 117 thousands in France), their further development can be expected, along with the increase in courier service demand. ${ }^{9}$

The research presented in this article poses a question: how significant are the dimensions of the $\mathrm{COO}$ in transport services (in courier services and low-cost airlines)? The article presents an attempt at defining an in-depth rate of the COO effect of the each analysed country in the reference to the transport services mentioned above, and at defining the relation between the $\mathrm{COO}$ effect of the particular country in terms of transport service evaluation and the readiness to buy and use this service.

The data were collected with the use of random questionnaire survey technique. The conclusions drawn from the research presented below may come as significant premises for the formation of service offer and promotion programmes for foreign entities which operate on the Polish market.

\section{The COO effect and its dimensions in marketing}

The COO effect is shaped by the factors which refer to the consumer's features (i.e. ethnocentrism, aversion to a particular country, stereotypes, dimensions

\footnotetext{
${ }^{7}$ Rynek ustug kurierskich: E-commerce nowym polem działania, www.dziennik.pl/artykuly/4641 19,rynek-uslug-kurierskich-e-commerce-nowym-polem-dzialania.html/?no_redirect=1 (24.05.2015).

${ }^{8}$ A. Marcysiak, K. Pieniak-Lendzion, M. Lendzion, Usługi kurierskie na rynku ustug logistycznych $w$ Polsce, Zeszyty Naukowe Uniwersytetu Przyrodniczo-Humanistycznego w Siedlcach No. 96, Siedlce 2013, p. 29.

${ }^{9}$ Rośnie rynek ustug kurierskich. Spodziewany jest wzrost liczby fuzji i przejęć, www.biznes.newseria.pl/news/telekomunikacja/rosnie_rynek_uslug,p1478075020 (24.05.2015).
} 
of national cultures, demographic factors) as well as to the level of the economic development level of the consumer's country. The discussed phenomenon is also affected by the evaluation of the product attributes: intrinsic ones (such as functionality of products, their types and complexity) and extrinsic ones (intangible qualities, such as the $\mathrm{COO}$, prices, brands, guarantees). The features of products listed above, along with individual factors which refer to the consumer (the aspect of consumption, ${ }^{10}$ the level of involvement, the type of involvement, the familiarity with the product and its significance) come as the moderators of the $\mathrm{COO}$ impact. ${ }^{11}$

Until now the research on the $\mathrm{COO}$ has referred to the broad scope of problems, such as: the impact of this phenomenon on the evaluation and the quality of a particular offer, perception of the value and the purchase risk, purchasing intentions and readiness to pay a specified price. ${ }^{12}$ This research has been focused on the analysis of different types of products, methods and variables.

The scientists have also considered the question of a multi-dimensional character of the $\mathrm{COO}$ effect. At first, they assumed the opinion that it is a one-dimensional phenomenon, however, this opinion evolved towards the assumption that it is a complex category. M.S. Roth and J.B. Romeo (1992) suggested a COO model consisting of four elements:

- innovativeness (understood as the use of modern technologies and technical advancement),

- design (appearance, style, colours and variety),

- prestige (exclusiveness, status, brand reputation),

- $\quad$ workmanship (reliability, durability, craft, the quality of workmanship). ${ }^{13}$

\footnotetext{
${ }^{10} \mathrm{P}$. Sharma, Demystifying cultural differences in country-of-origin effects: exploring the moderating roles of product type, consumption context, and involvement, "Journal of International Consumer Marketing" 2011, No. 23, Iss. 5, p. 344.

${ }^{11}$ M. Pharr, Synthesizing country-of-origin research from the last decade: is the concept still salient in an era of global brands?, "Journal of Marketing Theory \& Practice" 2005, Vol. 13, No. 4, p. 35-37.

12 The review of literature can be found in: J.M. Pharr, Synthesizing country-of-origin...; R.A. Peterson, A.J.P. Jolibert, A meta-analysis of country-of-origin effects, "Journal of International Business Studies" 1995, Vol. 26, No. 4, p. 83-101; S. Rezvani et al., A conceptual study on the country of origin effect on consumer purchase intention, "Asian Social Science" 2012, Vol. 8, No. 12, p. 205-205.

${ }_{13}$ The review of the methods applied in the research on the COE can be found in: M.S. Roth, J.B. Romeo, Matching product category and country image perception: a framework for managing country-of-origin effects, "Journal of International Business Studies" 1992, Vol. 3, No. 24, p. 477497; S. Bose, A. Ponnam, Country of origin effect on services: an evaluation of entertainment, "Managing Leisure" 2011, Vol. 2, No. 16, p. 98-107.
} 
Adopting the model described above for the requirements of the analysis of the entertainment sector, S. Bose and A. Ponnam (2011) suggested the following dimensions: innovativeness, variety, exclusiveness and quality. ${ }^{14}$

The authors of the article have attempted to modify the models described above by defining universal attributes which would be applicable to the analysis of various types of services, and assuming the following dimensions:

- innovativeness - the use of the most recent knowledge and technology,

- variety - appearance, style, the scope of an offer,

- prestige - exclusiveness, status, reputation,

- quality - reliability, durability, professionalism.

It should be noticed that the question whether the $\mathrm{COO}$ effect is a multi-dimensional phenomenon has not been explicitly decided by the abovementioned scientists. In their conclusions they presented the tendency to support the opinion that it belongs to a one-dimensional category.

\section{The research method}

In the research the technique of random questionnaire survey was applied. The respondents were asked to complete a questionnaire form which consisted of 5 parts, using the six-grade Likert's scale. In the first part, the respondents answered the questions concerning the image of some selected European countries, with the consideration of four criteria defined above, namely: innovativeness, variety, quality and prestige. In the second part the respondents were asked to determine the weight of each of four dimensions for the transport services. In the third part they were asked to determine their readiness to purchase the analysed services coming from the particular countries. In the fourth part the respondents were asked to define their level of knowledge about the analysed countries. The questionnaire form was ended with the personal information about the respondents. There were nine countries of the European Union selected for the analysis: Germany, Great Britain and France - the countries with strong, highly developed economies which represent the so called "old Union"; Sweden - the country from Northern Europe; Italy and Spain - the countries from Southern Europe; Lithuania and Hungary - the countries from Central and Eastern Europe which represent new members of the European Union; Poland - the respondents' home country.

The survey participants were 129 students of a business faculty, who studied at full-time and part-time study courses. This group included 55 men (42.63\%)

\footnotetext{
${ }^{14}$ S. Bose, A. Ponnam, Country of origin..., p. 98-107.
} 
and 74 women (57.37\%). The respondents' average age was $\mathrm{M}=23.73$ and the standard deviation was $S D=5.71$.

\section{The results of the survey}

In order to verify whether the particular dimensions of the $\mathrm{COO}$ are differentiated in the analysed transport services, the t-student test was carried out (the results are presented in table 1 ).

Table 1

The significance of the $\mathrm{COO}$ dimensions in transport services

\begin{tabular}{|c|c|c|c|c|c|c|}
\hline Dimensions & $\mathrm{M}$ & $\mathrm{SD}$ & $\mathrm{M}$ & $\mathrm{SD}$ & \multirow{2}{*}{$t$} & \multirow{2}{*}{$p$} \\
\cline { 1 - 5 } Courier services & \multicolumn{2}{c|}{ Low-cost airlines } & & \\
\hline Innovativeness & 4.349 & 1.268 & 4.550 & 1.252 & 1.74 & 0.08 \\
\hline Variety & 4.085 & 1.382 & 4.147 & 1.404 & 0.52 & 0.60 \\
\hline Quality & 4.705 & 1.327 & 4.426 & 1.425 & 2.41 & 0.02 \\
\hline Prestige & 3.806 & 1.289 & 3.907 & 1.417 & 0.80 & 0.42 \\
\hline
\end{tabular}

$\mathrm{df}=128, \mathrm{M}-$ mean, $\mathrm{SD}-$ standard deviation $\mathrm{t}-\mathrm{t}$-student test, $\mathrm{p}$ - level of the statistical significance Source: the authors' own study.

With the use of the six-grade scale, the most dimensions were evaluated as more than 4. It means that the particular $\mathrm{COO}$ dimensions are highly significant in transport services. Additionally, the lack of differences was pointed out in the evaluation of the significance which refers to the particular COO dimensions. Only the courier services were expected to be of higher quality comparing it with the quality of services offered by low-cost airlines.

In order to check whether the weight assigned to the particular dimensions is differentiated in the particular services, an analysis of variance with repeated measures was performed (for each service separately). A significant effect was noticed in the case of the dimensions in airline services $(F(3.384)=11.20 ; p<0.001)$. The dimension of innovativeness was assumed as statistically more significant than variety (NIR: $\mathrm{p}<0.001)$ and prestige $(N I R: \mathrm{p}<0.001)$. The weight of innovativeness was not significantly different from the weight of quality (NIR: $\mathrm{p}>0.05)$. The weight of variety was significantly lower than the weight of quality $(N I R: \mathrm{p}<0.05)$ and higher than the weight of prestige (NIR: $\mathrm{p}<0.05)$.

The analysis of variance referring to the courier services also indicated a significant dimension effect $(\mathrm{F}(3.384)=18.98 ; \mathrm{p}<0.001)$. The highest weight was assigned to the quality of services, and it was statistically significantly different 
from other dimensions (NIR: $\mathrm{p}<0.01)$. The weight assigned to prestige was statistically significantly lower than the weight of other dimensions (innovativeness:, NIR: $\mathrm{p}<0.001$; variety: NIR: $\mathrm{p}<0.05$, prestige NIR: $\mathrm{p}<0.001)$.

The analysis presented above indicated that the respondents assigned different weights to the particular COO dimensions in transport services. Roth and Romero (1992) averaged the significance of the dimensions for the service and the evaluation of the countries in terms of the dimensions. Based on that, they claimed that there is a compatibility between the product and the country if both averages are high or both are low. This method, however, seems to be inadequate if we realise that the particular dimensions are evaluated as differently significant - as it has been presented above. It seems important for further analyses to apply a rate which could answer the question: how highly are the COO dimensions evaluated for the services coming from the particular countries and, at the same time, how significant are these dimensions for the particular service.

This kind of rate was introduced in this paper: it is referred to as the weighted of $\mathrm{COO}$ effect and it is defined as the global perception of the $\mathrm{COO}$ of the service weighted by the significance of the particular dimensions in the particular service. This rate answers the question how highly the dimensions of innovativeness, variety, quality and prestige are evaluated for the services coming from the particular country, and how significant the dimensions are in the selected service. The higher the rate of the weighted $\mathrm{COO}$ effect is, the more positive global perception of the particular country becomes in the reference to the selected service. The weighted effect of the selected country $\mathrm{k}(\mathrm{k}=1, \ldots, 9)$ in the evaluation of the $\mathrm{i}^{\text {th }}$ service $(I=1,2)$ for a particular respondent can be defined by the following equation:

$$
U_{k, i}=\operatorname{innov}_{k} \cdot w_{\text {innov,i }}+\operatorname{var}_{k} \cdot w_{\mathrm{var}, i}+\operatorname{qual}_{k} \cdot w_{\text {qual }, i}+\operatorname{pres}_{k} \cdot w_{\text {pres }, i}
$$

where:

$w_{\text {innov, },} ; w_{\text {var, } i} ; w_{\text {qual, } i} ; w_{\text {pres }, i}$ weights, that is namely: the significance of the particular dimensions (respectively: innovativeness, variety, quality and prestige) for a particular respondent in the selection of the $\mathrm{i}^{\text {th }}$ service (low-cost airlines, courier services). These weights were obtained by asking the respondents to perform the following task: "Using the scale from 1 to 6 (where 1 - definitely not and 6 - definitely yes), please evaluate the significance of the features listed below for the particular service." 
innov $v_{k} ; \operatorname{var}_{k} ;$ qual $_{k} ;$ pres $_{k}$ - a consumer's perception of the particular dimension in the k country was obtained through the respondent's answer to the following task: „Using the scale from 1 to 6 (where 1 - definitely not and 6 - definitely yes), please evaluate innovativeness (and respectively: variety, quality and prestige) of products and services in the particular country."

Table 2 presents the weighted COO effect of the particular countries in terms of transport services.

Table 2

The values of the weighted $\mathrm{COO}$ effect in the low-cost airline services and courier services

\begin{tabular}{|l|c|c|c|c|c|c|}
\hline \multirow{2}{*}{ Country } & \multicolumn{2}{|c|}{$\begin{array}{c}\text { Low-cost airli- } \\
\text { nes }\end{array}$} & \multicolumn{2}{|c|}{ Courier services } & $\begin{array}{c}\text { Ranking of the } \\
\text { countries for } \\
\text { the low-cost } \\
\text { airlines }\end{array}$ & $\begin{array}{c}\text { Ranking of the } \\
\text { countries for the } \\
\text { courier services }\end{array}$ \\
\cline { 2 - 7 } France & 74.68 & 25.84 & 73.78 & 22.82 & 4 & 4 \\
\hline Spain & 65.68 & 22.59 & 64.76 & 19.95 & 6 & 6 \\
\hline Lithuania & 45.87 & 18.06 & 45.40 & 16.92 & 9 & 9 \\
\hline Germany & 87.83 & 26.35 & 87.54 & 25.21 & 1 & 1 \\
\hline Poland & 61.98 & 23.03 & 61.26 & 21.52 & 7 & 7 \\
\hline Sweden & 77.98 & 27.82 & 78.10 & 27.59 & 3 & 3 \\
\hline UK & 80.77 & 25.00 & 79.91 & 22.63 & 2 & 2 \\
\hline Hungary & 54.79 & 20.49 & 54.61 & 19.64 & 8 & 8 \\
\hline Italy & 69.16 & 22.99 & 68.48 & 21.59 & 5 & 5 \\
\hline
\end{tabular}

$\mathrm{M}$ - mean, SD - standard deviation. The highest value of the weighted COO effect which was possible to be obtained was $6 \times 6 \times 4=144$, and the lowest value was 4 .

Source: the authors' own study.

Considering low-cost airlines and courier services - the highest weighted COO effect is indicated for Germany and the lowest - for Lithuania. In other cases these rates do not differ significantly between the discussed services in the particular countries. The ranking of the weighted $\mathrm{COO}$ effect of low-cost airlines is overlapped with the ranking of the courier services in the particular countries. It means that if a country is highly evaluated according to low-cost airline services, the courier services in that country are also highly evaluated. Hence, the analysed services are perceived by the respondents in a similar way. The least differentiation in the respondents' evaluation was indicated in Lithuania. It means that most respondents gave this country the lowest grade in their evaluation. The result obtained by Germany, namely: the weighted effect twice as high as the weighted effect obtained 
by Lithuania is also worth noticing. It indicates that Germany is far more positively evaluated in terms of transport services than Lithuania.

Further detailed analyses allow us to complete the thesis concerning the validity of differentiation of the COO dimensions. This fact is proved by the abovementioned results and the results which were previously published. ${ }^{15}$ However, it should be emphasized that there is an internal differentiation of the weights assigned to the $\mathrm{COO}$ dimensions in the particular service, and at the same time, there is a strong relation between them. It is confirmed by correlation outcomes. Correlation was calculated for evaluations of dimensions' significance for the given service (presented by table 3 ).

Table 3

The coefficients of the correlation between the evaluation significance of the $\mathrm{COO}$ dimensions for the given service

\begin{tabular}{|l|c|c|c|c|}
\hline \multirow{2}{*}{ Dimensions } & \multicolumn{4}{|c|}{ Courier services } \\
\cline { 2 - 5 } & $\begin{array}{c}\text { innovative- } \\
\text { ness }\end{array}$ & variety & quality & prestige \\
\hline Innovativeness & & $0.63 *$ & $0.37 *$ & $0.35^{*}$ \\
\hline Variety & $0.63^{*}$ & & $0.42^{*}$ & $0.42^{*}$ \\
\hline Quality & $0.37^{*}$ & $0.42 *$ & & $0.37 *$ \\
\hline Prestige & $0.35^{*}$ & $0.42^{*}$ & $0.37 *$ & \\
\hline
\end{tabular}

\begin{tabular}{|c|c|c|c|}
\hline \multicolumn{4}{|c|}{ Low-cost airlines } \\
\hline $\begin{array}{c}\text { innovative- } \\
\text { ness }\end{array}$ & variety & quality & prestige \\
\hline & $0.42^{*}$ & $0.65^{*}$ & $0.49^{*}$ \\
\hline $0.42^{*}$ & & $0.43^{*}$ & $0.43^{*}$ \\
\hline $0.65^{*}$ & $0.43^{*}$ & & $0.58^{*}$ \\
\hline $0.49^{*}$ & $0.43^{*}$ & $0.58^{*}$ & \\
\hline
\end{tabular}

$* \mathrm{p}<0.001$

Source: the author's own study.

The correlation results indicate that if, for example, the variety significance for the courier services was highly evaluated, then it was bound with high innovativeness significance for these services. In the case of low-cost airlines there was a similar relation between innovativeness and quality. All these relations were statistically significant at the level of $\mathrm{p}<0.001$.

In order to verify if there is a relation between the weighted $\mathrm{COO}$ effect in transport services and readiness to purchase these services in a given country, the analysis of rankings has been performed along with a correlation analysis. The obtained means of the declared readiness to purchase the service in a particular

\footnotetext{
${ }^{15}$ E. Magier-Łakomy, M. Boguszewicz-Kreft, Dimensions of the country of origin effect and their measurement, "Annales Universitatis Mariae Curie-Skłodowska Lublin" 2015, Vol. 49, No. 3, p. 125134; M. Boguszewicz-Kreft, E. Magier-Łakomy, Wizerunek produktów i ustug z wysoko rozwiniętych krajów europejskich - analiza wielowymiarowości efektu kraju pochodzenia, Studia Ekonomiczne. Zeszyty Naukowe Uniwersytetu Ekonomicznego w Katowicach (being printed).
} 
country, ${ }^{16}$ and the country rankings created on this basis indicate some differences between the discussed service categories. The readiness to purchase the particular service differentiates countries more than the weighted $\mathrm{COO}$ effect. The weighted effect characteristic for Poland transport services reached a low level (the $7^{\text {th }}$ position out of total 9; see: table 4 ) and the readiness to purchase the low-cost airline service in Poland maintained at the same position (the $7^{\text {th }}$ position). However the readiness to purchase the courier services reached quite a high level (the $3^{\text {rd }}$ position).

Table 4

The readiness to purchase low-cost airline and courier services in the given countries

\begin{tabular}{|l|c|c|c|c|c|c|}
\hline \multirow{2}{*}{ Country } & \multicolumn{3}{|c|}{ Low-cost airlines } & \multicolumn{3}{c|}{ Courier services } \\
\cline { 2 - 7 } & $\mathrm{M}$ & $\mathrm{SD}$ & ranking & $\mathrm{M}$ & $\mathrm{SD}$ & ranking \\
\hline Lithuania & 2.88 & 1.33 & 9 & 3.06 & 1.23 & 8 \\
\hline Hungary & 3.52 & 1.24 & 8 & 3.41 & 1.10 & 7 \\
\hline Poland & 3.80 & 1.18 & 7 & 4.06 & 1.18 & 3 \\
\hline Spain & 3.84 & 1.20 & 6 & 3.70 & 1.01 & 6 \\
\hline Italy & 3.89 & 1.03 & 5 & 3.77 & 1.02 & 5 \\
\hline France & 3.95 & 1.33 & 4 & 3.98 & 1.32 & 4 \\
\hline Sweden & 4.25 & 1.18 & 3 & 4.23 & 1.09 & 2 \\
\hline Germany & 4.40 & 1.17 & 2 & 4.52 & 1.09 & 1 \\
\hline UK & 4.55 & 0.93 & 1 & 4.23 & 1.12 & 2 \\
\hline
\end{tabular}

Source: the authors' own study.

In order to verify to what extent the weighted $\mathrm{COO}$ effect of the particular country for transport services is connected with the declared readiness to purchase these services in the particular country, the correlation between these two variables was calculated. ${ }^{17}$ All the correlations were statistically significant $(p<0.001)$. It means that the higher weighted COO effect of the country is in the evaluation of the service, the higher readiness to purchase this service in this particular country becomes. Relatively lower correlations obtained by Great Britain in the reference to the low-cost airlines may be surprising, as well as those obtained by Germany in the reference to the courier services. It may indicate that

16 The results obtained through the answers to the following task: Using the scale from 1 to 6 ( 1 definitely no, 6 - definitely yes), please state whether you would be ready to purchase the services listed below if they came from the given country.

${ }^{17}$ A different type of statistical analysis in the similar research problems; J.B. Berentzen et al., Does "Made in ..." Also apply to services? An empirical assessment of the country-of-origin effect in service settings, "Journal of Relationship Marketing" 2008, Vol. 7, No. 4, p. 391-393. 
we can predict the readiness to purchase transport services in these countries on the basis of the $\mathrm{COO}$ effect to a smaller extent. However, the general conclusion is possible: the results presented above, as well as the results presented by Berentzen et al., prove the influence of the country of origin on customers' purchase intentions.

\section{Conclusions}

The analysis of the collected data allowed the authors to draw the following conclusions:

1. The COO dimensions are important for transport services.

2. The particular dimensions are significant for transport services to a different extent.

3. The analysed countries present a highly differentiated weighted $\mathrm{COO}$ effect in the service evaluation.

4. The weighted $\mathrm{COO}$ effects of the particular country for low-cost airline and courier services are the same.

5. Consumers differentiate countries more by their readiness to purchase than by the $\mathrm{COO}$ effect.

6. There is a strong correlation between the weighted $\mathrm{COO}$ effect of the country and the readiness to purchase the particular service in this country: the higher effect appears to be, the higher readiness to purchase the service becomes.

\section{Bibliography}

Berentzen J.B. et al., Does “Made in ...” Also apply to services? An empirical assessment of the country-of-origin effect in service settings, "Journal of Relationship Marketing" 2008, Vol. 7, No. 4.

Boguszewicz-Kreft M., Efekt kraju pochodzenia w ushugach, w: Sektor ustug - uwarunkowania i tendencje rozwoju, Prace Naukowe Uniwersytetu Ekonomicznego we Wrocławiu nr 353, Wyd. Uniwersytetu Ekonomicznego, Wrocław 2014.

Boguszewicz-Kreft M., Magier-Łakomy E., Wizerunek produktów i ushug z wysoko rozwiniętych krajów europejskich - analiza wielowymiarowości efektu kraju pochodzenia, Studia Ekonomiczne. Zeszyty Naukowe Uniwersytetu Ekonomicznego w Katowicach (being printed).

Bose S., Ponnam A., Country of origin effect on services: an evaluation of entertainment, „Managing Leisure” 2011, Vol. 2, No.16.

Civil Aviation Authority, Statistics by carriers, www.ulc.gov.pl/pl/czesto-zadawanepytania-faq/348-ler/3725-statystyki-wg-przewoznikow.

Czakon W., Metodyka systematycznego przegladu literatury, in: Podstawy metodologii badań w naukach o zarzadzaniu, ed. W. Czakon, Oficyna Wolters Kluwer business, Warszawa 2013. 
Magier-Łakomy E., Boguszewicz-Kreft M., Dimensions of the country of origin effect and their measurement, "Annales Universitatis Mariae Curie-Skłodowska Lublin" 2015, Vol. 49, No. 3.

Marcysiak A., Pieniak-Lendzion K., Lendzion M., Ustugi kurierskie na rynku usług logistycznych $w$ Polsce, Zeszyty Naukowe Uniwersytetu Przyrodniczo-Humanistycznego w Siedlcach No. 96, Siedlce 2013.

Peterson R.A., Jolibert A.J.P., A meta-analysis of country-of-origin effects, "Journal of International Business Studies" 1995, Vol. 26, No. 4.

Pharr J.M., Synthesizing country-of-origin research from the last decade: is the concept still salient in an era of global brands?, "Journal of Marketing Theory \& Practice" 2005, Vol. 13, No. 4.

Rezvani S. et al., A conceptual study on the country of origin effect on consumer purchase intention, "Asian Social Science" 2012, Vol. 8, No.12.

Rośnie rynek ustug kurierskich. Spodziewany jest wzrost liczby fuzji i przejęć, www.biznes.newseria.pl/news/telekomunikacja/rosnie_rynek_uslug,p1478075020.

Roth M.S., Romeo J.B., Matching product category and country image perception: a framework for managing country-of-origin effects, "Journal of International Business Studies" 1992, Vol. 3, No. 24.

Rynek ustug kurierskich: E-commerce nowym polem działania, www.dziennik.pl/artykuly/464119,rynek-uslug-kurierskich-e-commerce-nowym-polem-dzialania.html/?no_redirect $=1$.

Sharma P., Demystifying cultural differences in country-of-origin effects: exploring the moderating roles of product type, consumption context, and involvement, "Journal of International Consumer Marketing" 2011, No. 23, Iss. 5.

UOKiK: Wpływ liberalizacji rynku połaczeń lotniczych na konkurencję na tym rynku, Departament Analiz, luty 2010.

\section{EFEKT KRAJU POCHODZENIA W WYBRANYCH USEUGACH TRANSPORTOWYCH}

\section{Streszczenie}

Efekt kraju pochodzenia jest wielowymiarowy. Nieuwzględnienie wkładu poszczególnych wymiarów w ocenie wybranych usług może skutkować uproszczonymi wnioskami. Celem prezentowanych badań było: 1) wyznaczenie pogłębionego wskaźnika efektu COO w ocenie usług transportowych; 2) ustalenie związku między efektem COO danego kraju w ocenie usługi transportowej a gotowością do jej zakupu. Rezultaty wskazują na silny związek między efektem COO kraju a gotowością do zakupu danej usługi w tym kraju: im wyższy efekt COO tym większa gotowość do zakupu usługi.

Słowa kluczowe: efekt kraju pochodzenia, usługi transportowe, wyniki badań

Ttuamczenie: Monika Boguszewicz-Kreft, Ewa Magier-Eakomy, Katarzyna Sokołowska 